\title{
Proposal of Anatomical Terms for Alterations in Tooth Size: "Microdontia and Macrodontia"
}

\author{
Propuesta de Términos Anatómicos para las Alteraciones de Tamaño Dentario: \\ "Microdoncia y Macrodoncia"
}

Paulina Agurto S. ${ }^{1}$; Christopher Nicholson ${ }^{1,3} \&$ Mariano del Sol ${ }^{1,2}$

\begin{abstract}
AGURTO, S. P.; NICHOLSON, C. \& DEL SOL, M. Proposal of anatomical terms for alterations in tooth size: "microdontia and macrodontia". Int. J. Morphol., 37(1):375-378, 2019.

ABSTRACT: There are 76 dentistry terms used in the Terminologia Anatomica, which is a very small number for the existing nomenclature, which uses many terms with Greek roots and eponyms. The aim of this study was to propose terms in Latin and their respective translations into English and Spanish for macrodontia, microdontia and their classifications. We conducted a review of the Terminologia Anatomica and the literature in articles and texts. Then, we translated both terms etymologically from the Greek to obtain our proposal in Latin, Nanismus dentarius for microdontia and Gigantismus dentarius for macrodontia and their subsequent translations into English and Spanish. We consider it necessary to eliminate relative generalized size anomalies as they are an alteration in the size of the dental arches and not the dental structure itself. We can conclude that there are still many terms that are incorrectly named according to etymology and language, which is why further analysis is needed to make changes and with them a real contribution to morphological sciences.
\end{abstract}

KEY WORDS: Macrodontia; Microdontia; Terminologia Anatomica.

\section{INTRODUCTION}

The urgent need for a common vocabulary for all anatomical structures for use by all professionals in the health sciences led to the creation of the Basle Nomina Anatomica in 1895. This recommends that a single name be used for each structure that is descriptive and brief, eliminating eponyms, and that their translation to the local language be as faithful as possible, only for education purposes (Federative Committee on Anatomical Terminology, International Federation of Associations of Anatomists, 2011).

However, for dentistry the list is very short, with only 76 terms being found in the Teeth category, of which few anatomical variations are included. Thus, many terms in Greek and eponyms are used, which neither represent nor adequately define the normal anatomy and variations of dental structures.

An example of this is alterations in tooth size such as microdontia and macrodontia.
Microdontia: This term is used for teeth that are smaller in size or volume than normal (Altug-Atac \& Erdem, 2007), which can be associated with an autosomal dominant pattern (Sapp et al., 2005). This term is not applied to supernumeraries.

According to the number of teeth affected by microdontia, two types are recognized:

Partial microdontia: This is the most common and occurs in one or more teeth, whose anatomy can be normal or with coronal deformity. It mainly affects the permanent upper lateral incisors, unilaterally or bilaterally (Fig. 1), but also upper third molars (Bäckman \& Wahlin, 2001; Mazariegos \& Corzo, 2013).

Generalized microdontia: The teeth of both dental arches are uniformly smaller than normal, which occurs in rare disorders such as hypophyseal dwarfism, where this dental pathology is called true generalized microdontia (Fig. 2) to

\footnotetext{
${ }^{1}$ Programa de Doctorado en Ciencias Morfológicas, Facultad de Medicina, Universidad de La Frontera, Temuco, Chile.

${ }^{2}$ Center of Excellence in Morphological and Surgical Studies (CEMyQ), Universidad de La Frontera, Temuco, Chile.

${ }^{3}$ Núcleo de Idiomas, Facultad de Estudios Interdisciplinarios, Universidad Mayor, Sede Temuco, Chile.
} 


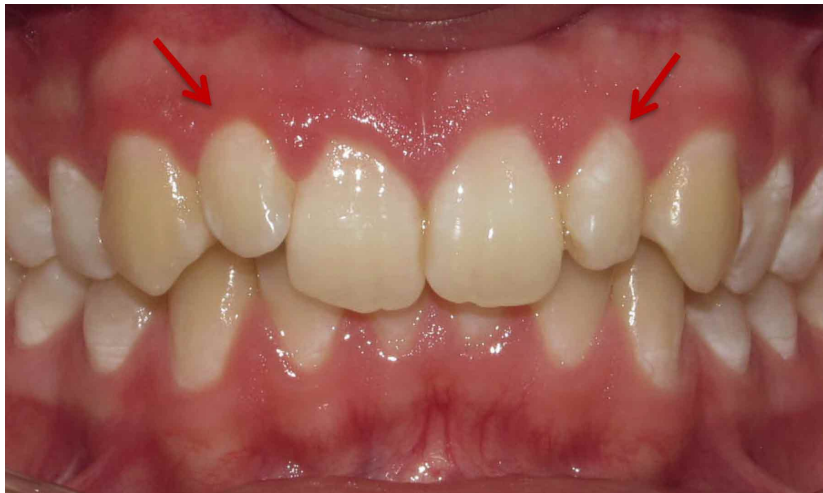

Fig. 1. Bilateral partial microdontia of the upper lateral incisors.

differentiate it from relative generalized microdontia, where the maxilla are larger than normal, giving a false impression of small teeth. Other syndromes that can present microdontia are: Down syndrome, hemifacial microsomia and hereditary anhidrotic ectodermal dysplasia (Sanz Coarasa et al., 2012).

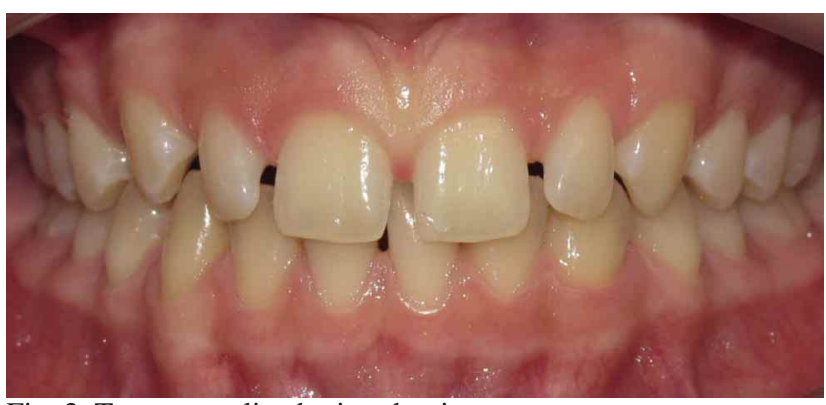

Fig. 2. True generalized microdontia.

Macrodontia, on the other hand, is the term used to designate teeth that are larger than normal. It is of unknown etiology, but it is associated with an autosomal dominant pattern of inheritance. As with microdontia, two types are described:

Partial macrodontia: This occurs in one or more teeth, whose anatomy can be normal or with coronal deformity. The teeth mainly affected are the upper central incisors (Fig. 3 ) and lower third molars. In the case of hemifacial hypertrophy, the affected side presents macrodontic teeth (Namdar \& Atasu, 1999).

Generalized macrodontia: Large teeth in both dental arches. This is also subdivided into true generalized macrodontia, as in hypophyseal gigantism. In relative generalized macrodontia, the maxilla are smaller than normal, but the teeth are normal (Langlais et al., 2011).

The aim of this study was to propose suitable terms for macrodontia, microdontia and their classifications.

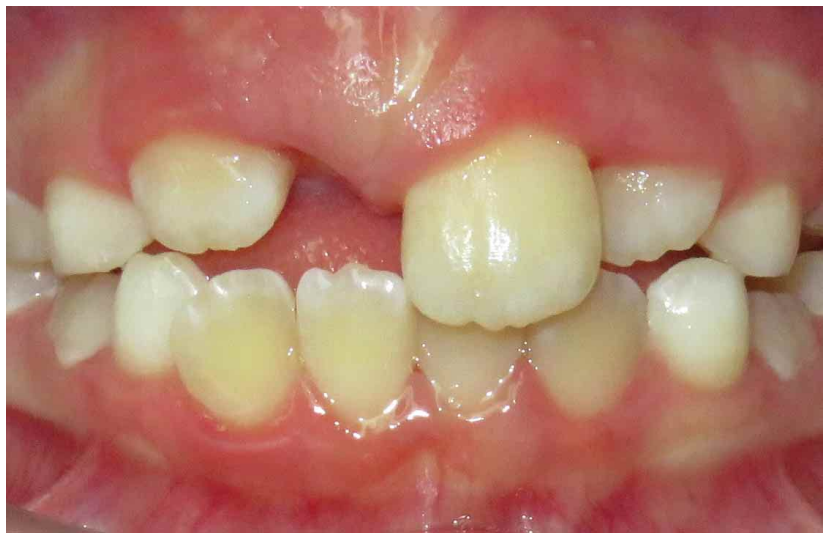

Fig. 3. Partial macrodontia.

\section{MATERIAL AND METHOD}

A review was conducted of the 2011 edition of Terminologia Anatomica, in category A05.1.03.001 Teeth. The terms were analyzed one by one, where alterations in tooth size were found not to be indexed.

Parallel to this, a scientific search was made on the Internet through PubMed, texts, articles and dictionaries in order to verify the terms and their definitions so as to make proposals and translate them in the best possible way.

Then, the terms macrodontia and microdontia were translated into Latin as the official language, as well as into English and Spanish through the use of dictionaries in each language.

\section{RESULTADOS}

A translation of the terms microdontia and macrodontia obtained the following etymological definition:

Microdontia: from the Greek $\mu \imath \kappa \rho \circ \varsigma$ (micro): small; ódovৎ/

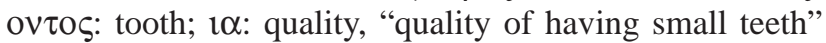
(Pabon, 2006).

Macrodontia: from the Greek $\mu \alpha \kappa \rho \circ \varsigma$ (macro): large, long;

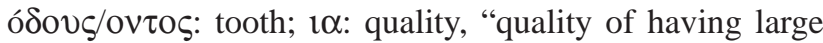
teeth" (Pabon) (Table I). ó

Table I. Terms with Greek etymology used for alterations in tooth size

\begin{tabular}{ll}
\hline Greek & English \\
\hline$\mu 1 \kappa \rho \sigma \varsigma$ & Microdontia \\
$\sigma \delta \sigma \nu \varsigma$ & Macrodontia \\
\hline
\end{tabular}


We propose a translation to Latin, English and Spanish respectively of both alterations in size and their classifications (Table II).

Given that the sub-classification of relative generalized macrodontia and microdontia does not refer to an anomaly of tooth size (normal sized teeth), but rather to an alteration in the size of the dental arches (Gómez de Ferraris \& Muñoz Campos, 2009), we consider that it should be eliminated.

Among the searches performed, it was discovered that the term "macrodontia" is also given to a beetle from the genus of longhorn beetle native to South America (Hogue, 1993); therefore, it would not be of exclusive use for an alteration in human tooth size.

It was also found that these alterations in tooth size (macrodontia and microdontia) are indexed in the International Classification of Diseases (ICD-11) in Item 20 Developmental Anomalies, in LA 30 Structural developmental anomalies of teeth and periodontal tissues, encoded in LA30.4 Abnormalities of size or forms of teeth (International Clasification of Deseases, 2018).

Table II. Translation and proposal of the terms used for alterations in tooth size and their types.

\begin{tabular}{llll}
\hline $\begin{array}{l}\text { Greek-English } \\
\text { (Latin alphabet) }\end{array}$ & Latin & English & Spanish \\
\hline Microdontia & Nanismus Dentarius & Dental Dwarfism & Enanismo Dentario \\
Partial Microdontia & Nanismus Dentarius Parcialis & Dental Dwarfism Parcial & Enanismo Dentario Parcial \\
Generalized Microdontia & Nanismus Dentarius Generalis & Dental Dwarfism Generalized & Enanismo Dentario Generalizado \\
Macrodontia & Gigantismus Dentarius & Dental Giantism & Gigantismo Dentario \\
Partial Macrodontia & Gigantismus Dentarius Parcialis & Dental Giantism Parcial & Gigantismo Dentario Parcial \\
Generalized Macrodontia & Gigantismus Dentarius Generalis & Dental Giantism Generalized & Gigantismo Dentario Generalizado \\
\hline
\end{tabular}

\section{DISCUSSION}

The justification of this proposal is that the etymological definition from the Greek for microdontia and macrodontia is the quality of small and large teeth, respectively. But small or large compared to what? By contrast, the words dwarfism and gigantism reflect an alteration in size compared to a normal pattern.

In addition, in dentistry the English and Spanish terms for root dwarfism and root gigantism are currently used for rootsanatomically disproportionate to the coronal length and volume (Bordoni et al., 2010). In our opinion, these are simple and widely used terms in dentistry jargon, which is why we reached a consensus that the most suitable words for the Latin, English and Spanish translations of microdontia is "Dental dwarfism" and "Dental gigantism" for macrodontia (Table II).

The indexing of these anomalies in the ICD-11 seems debatable to us, as we believe alterations in tooth size are not pathologies, but rather anatomical variations of the tooth structure.

After compiling the data, we can conclude that there are still many terms in dentistry that are not on the list of the Official Terminologia Anatomica. Therefore, it seems to us that a greater effort should be made to unify criteria in the Terminologia Anatomica, making an exhaustive review of the terms in use, so that in future they can be suitably translated to both the official language (Latin) as well as to English and Spanish, together with other terms of dentomaxillary structures and anatomical variations that have not yet been indexed. In turn, these must be proposed for observations and comments by experts at the Iberian-Latin-American Symposia of Morphological Terminology (SILAT) in order to make a real contribution to morphological sciences.

AgURTO, S. P.; NICHOLSON, C. \& DEL SOL, M. Propuesta de términos anatómicos para las alteraciones de tamaño dentario: "microdoncia y macrodoncia". Int. J. Morphol., 37(1):375-378, 2019.

RESUMEN: En Odontología son 76 los términos utilizados en Terminologia Anatomica, lo que es un número muy reducido para la nomenclatura existente, en la que aún se usan muchos términos con raíces griegas y epónimos. El objetivo de éste estudio fue proponer términos en latín y sus respectivas traducciones al inglés y español, para Macrodoncia, Microdoncia y sus clasificaciones. Realizamos una revisión de la Terminologia Anatomica y de la literatura existente en artículos y textos. Posteriormente tradujimos etimológicamente ambos términos desde el griego, para así lograr nuestra propuesta en latín, Nanismus dentarius para Microdoncia y Gigantismus dentarius para Macrodoncia, y su posterior traducción al inglés y español. Consideramos necesario eliminar las anomalías de tamaño generalizadas relativas, por corresponder en sí, a una alteración de tamaño de los Arcos Dentales y no de la estructura dentaria propiamente tal. Podemos concluir que existen aún muchos términos que no se encuentran correctamente nominados según etimología e idioma, por lo que se hace necesario un mayor análisis, para así gestar los cambios y hacer un real aporte a las Ciencias Morfológicas.

PALABRAS CLAVE: Macrodoncia; Microdoncia; Terminologia Anatomica. 


\section{REFERENCES}

Altug-Atac, A. T. \& Erdem, D. Prevalence and distribution of dental anomalies in orthodontic patients. Am. J. Orthod. Dentofacial Orthop., 131(4):5104, 2007.

Bäckman, B. \& Wahlin, Y. B. Variations in number and morphology of permanent teeth in 7-year-old Swedish children. Int. J. Paediatr. Dent., 11(1):11-7, 2001.

Bordoni, N.; Escobar Rojas, A. \& Castillo Mercado, R. Odontología Pediátrica. La Salud Bucal del Niño y el Adolescente en el Mundo Actual. Buenos Aires, Médica Panamericana, 2010.

Gómez de Ferraris, M. E. \& Muñoz Campos, A. Histología, Embriología e Ingeniería Tisular Bucodental. Buenos Aires, Médica Panamericana, 2009.

Federative Committee on Anatomical Terminology. International Federation of Associations of Anatomists. Terminologia Anatomica. International Anatomical Terminology. Stuttgart, Thieme, 2011

Hogue, C. L. Latin American Insects and Entomology. Berkeley, University of California Press, 1993. pp.280-1.

International Clasification of Deseases (ICD). ICD-11. Geneva, World Health Organization, 2018. Available from: http://www.who.int/classifications/ icd/en/

Langlais, R. P.; Miller, C. S. \& Nield-Gehrig, J. S. Atlas a Color de Enfermedades Bucales. Ciudad de México, El Manual Moderno, 2011.

Mazariegos, H. C. \& Corzo, M. D. A. Alteraciones de tamaño, forma y número en piezas dentales. San Carlos de Guatemala, Facultad de Odontología, Universidad de San Carlos de Guatemala, 2013. Available from: h t t p ://www.odontocat.com/odontocat/nouod 2/pdf/ article\%20cita\%20odt\%2035.pdf

Namdar, F. \& Atasu, M. Macrodontia in association with a contrasting character microdontia. J. Clin. Pediatr. Dent., 23(3):271-4, 1999.

Pabon, J. Diccionario Manual Griego, Griego clásico-Español. 19ª ed. Barcelona, VOX, 2006.

Sanz Coarasa, A.; Pérez Vera, A. \& Barbería Leache, E. Alteraciones dentarias de número y forma, en niños sin malformaciones ni síndromes. Madrid, Universidad Complutense de Madrid, 2012. Available from: en: https://www.researchgate.net/profile/Elena_Barberia/publication/ 257919055 Alteraciones_Dentarias_de Numero_y_Forma_en_ninos_sin malformaciones_ni_sindromes/links/004635261282baf0ba000000/Alteraciones-Dentarias-de-Numero-y-Forma-en-ninos-sin-malformacionesni-sindromes.pdf

Sapp, J.; Eversole, L. \& Wysocky, G. Patología Oral y Maxilofacial Contemporánea. 2a ed. Madrid, Elsevier, 2005.
Corresponding author:

Paulina Agurto S.

Universidad de La Frontera

Temuco

CHILE

Email: pagurodo@gmail.com

Recibido : 11-10-2018

Aceptado: 22-11-2018 